\title{
Biological data extraction from imagery - How far can we go? A case study from the Mid-Atlantic Ridge
}

\author{
Daphne Cuvelier ${ }^{a, b, *}$, Fanny de Busserolles ${ }^{a}$, Romain Lavaud ${ }^{a}$, Estelle Floc'h ${ }^{a}$, Marie-Claire Fabri ${ }^{a, c}$, \\ Pierre-Marie Sarradin ${ }^{a}$, Jozée Sarrazin ${ }^{a}$
}

\footnotetext{
a Ifremer, Centre de Brest, Département Ressources physiques et Ecosystèmes de fond de Mer, Institut CarnotEDROME, Unité de recherche EEP, Laboratoire Environnement Profond, 29280 Plouzané, France

b Instituto do Mar (IMAR) \& Department of Oceanography and Fisheries, University of the Azores, 9901-862 Horta, Portugal

' Ifremer, Centre de Méditerranée, Département Océanographie et Dynamique des Ecosystèmes, Laboratoire Environnement Ressources, 83500 La Seyne sur Mer, France
}

\author{
*: Corresponding author : Daphne Cuvelier, Tel.: +33 (0) 298224329 ; fax: +33 (0) 298224757 ; \\ email address : daphne.cuvelier@ifremer.fr ; daphne.cuvelier@gmail.com
}

\begin{abstract}
:
In the past few decades, hydrothermal vent research has progressed immensely, resulting in higherquality samples and long-term studies. With time, scientists are becoming more aware of the impacts of sampling on the faunal communities and are looking for less invasive ways to investigate the vent ecosystems. In this perspective, imagery analysis plays a very important role. With this study, we test which factors can be quantitatively and accurately assessed based on imagery, through comparison with faunal sampling. Twelve instrumented chains were deployed on the Atlantic Eiffel Tower hydrothermal edifice and the corresponding study sites were subsequently sampled. Discrete, quantitative samples were compared to the imagery recorded during the experiment. An observereffect was tested, by comparing imagery data gathered by different scientists. Most factors based on image analyses concerning Bathymodiolus azoricus mussels were shown to be valid representations of the corresponding samples. Additional ecological assets, based exclusively on imagery, were included.
\end{abstract}

\section{Highlights}

Comparison between imagery analyses and corresponding discrete samples at a hydrothermal vent. Most factors based on image analyses of the dominant mytilid species were shown to be valid representations of the reality. Differences in faunal abundances between the two techniques are discussed. Ecological assets based exclusively on imagery analyses, e.g. microbial coverage, were included. Ecological factors that can be quantitatively assessed based on imagery and sampling at hydrothermal vents are highlighted.

Keywords: Hydrothermal vents ; Image analyses ; Deep ocean ; Taxonomic diversity ; Mid-Atlantic Ridge ; Data processing ; Benthic ecology 
$\underline{1 . \text { Introduction }}$

For the past few decades, deep-sea environments such as hydrothermal vents have been intensively studied by researchers worldwide. These extreme ecosystems are traditionally characterized by their remoteness (both from shore as in depth), and hostile environment (e.g. elevated temperatures, high hydrogen sulphide concentrations, steep chemical gradients). The chemosynthetic micro-organisms present at hydrothermal vents support very specific faunal assemblages. In order to increase our knowledge about the functioning and dynamics of vent ecosystems and their associated communities, faunal sampling is considered fundamental. Information collected through sampling on species composition, densities and biomass is, as such, essential to understand community ecology and biological productivity (Juniper et al., 1998). In this perspective, collecting animals is also crucial to study organism's physiology. With time, new techniques have been developed, allowing more precise analyses, higher quality samples and long-term studies.

Behind this progress, however, the question of the potential effects of unregulated sampling on these isolated ecosystems arises (Tyler et al., 2005). At hydrothermal vents, sampling is carried out with manned submersibles and Remotely Operated Vehicles (ROV's) which use their robust manipulator arms to sample the uneven and mostly hard substrata inhabited by vent organisms. The irregularity of these sampling surfaces makes quantitative sampling complicated and can result in local perturbations, lastingly changing fluid flow patterns and faunal communities. Such fluid flow modifications were shown to have a profound influence on local assemblages (Hessler et al., 1985; 1988; Fustec et al., 1987; Tunnicliffe, 1991; Sarrazin et al., 1997; 2002; Shank et al., 1998). Despite the precautions taken in choosing more easily accessible sites and relatively flat surfaces, sampling at vents remains intricate and can still be disturbing for faunal communities. This threat was recognised by vent researchers early on (Tyler et al., 2005) but only a few studies have been carried out on sampling impacts. Tunnicliffe (1990) is one of those few studies that assessed sampling effects on deep-sea hydrothermal vents and its fauna and demonstrated that the local vent community, in this case siboglinid polychaetes, had major difficulties to maintain itself after such an anthropogenic disturbance, resulting in a lack of subsequent colonization of the 
sampling effects, the faunal community, depending on the scale of sampling, may take up to several years to regain its original state (i.e. prior to sampling).

All submersibles and ROV's are equipped with piloting cameras that record imagery footage while diving and carrying out experiments. Contrastingly to sampling, image analysis is a non-invasive technique, which is also one of its greatest advantages. Moreover, imagery analysis permits investigating a larger surface (larger spatial coverage) than discrete sampling and therefore gives a more extended overview of the habitat and faunal communities. It is also more random than sampling, especially in the type of irregular terrain encountered at vents. Imagery analysis has been used to estimate surface areas, faunal coverage and the presence of associated fauna in a variety of ecosystems, such as coral reefs and coastal habitats (Norris et al., 1997; Magorrian \& Service, 1998; Ninio et al. 2000). At hydrothermal vents, imagery analysis already proved its value as it is an indispensable, and often the only, tool available in analysing community distribution and temporal variations (Desbruyères, 1998; Sarrazin et al., 1997; Shank et al., 1998; Tunnicliffe et al. 1997; Desbruyères et al., 2001; Tsurumi and Tunnicliffe 2001; Shank et al. 2003; Copley et al 2007; Nees et al. 2008; Marcus et al. 2009; Cuvelier et al., 2009, 2011a, b; Podowski et al., 2009; Fabri et al., 2011). Nevertheless, not all parameters are easy to assess based on imagery, and even while video studies are not invasive, they often require ground-truthing with collection of discrete samples at some stage in the investigation (Godet et al., 2010). However, once the connection between what we see and what we sample is established, visual recognition can be used to assess faunal distributions and physico-chemical environmental changes over time and on larger scales (Cuvelier et al., 2011a, b). With all that said, the question remains: how far can we go with imagery analyses without compromising on accurateness?

Currently, hydrothermal vents are somewhat "protected" in the sense that an international code of conduct was drawn up by the international scientific community (Tyler et al., 2005; Devey et al., 2007). The world's first deep-sea Marine Protected Area (MPA) was established in 2003 on the Endeavour segment on the Juan de Fuca Ridge (Canada, Devey et al., 2007). In the Atlantic, the Lucky Strike vent field was proposed as an important conservation area (Azores, Santos et al., 2003) and was included in the Oslo and Paris Conventions network of MPA's in 2007. It was also accepted in 2009 by the European Community as a Site of Community Importance under the Natura 2000 network (O.J. L 344, 2009). The goal of these MPA's is to preserve the integrity of hydrothermal ecosystems 
101 including the species and habitats to allow a better understanding of their natural diversity, productivity and dynamics. These protective measures do not allow sampling at certain sites and therefore emphasize the increasing importance of imagery and the accurateness of its interpretations in monitoring natural dynamics.

This paper concurrently investigates the potential and limitations of imagery analyses. In addition, we highlight complementary features that can only be extracted from imagery and are thus an asset to discrete sampling. As part of an in-depth ecological study, twelve instrumented chains equipped with temperature probes were deployed on visibly different faunal assemblages on the Eiffel Tower edifice (Lucky Strike vent field, Mid-Atlantic Ridge MAR). These twelve sites were thoroughly investigated, comparing imagery analyses with the corresponding ground-truth samples. In order to evaluate possible subjectivity in analysing imagery, we also compared the imagery analyses carried out by two different scientists to evaluate the observer's effect. The major objective of this study is to compare the results obtained by video imagery with those obtained through quantitative sampling.

\section{Material \& Methods}

\subsection{Study site}

Data gathering for this study was carried out during the MoMARETO cruise (2006) which took place in the MAR region, situated south-west of the Azores Triple Junction (ATJ). Data were collected on the hydrothermal Eiffel Tower edifice, a sulphide structure located south-east of the central lava lake of the Lucky Strike vent field. This 11 meter high edifice, situated at a depth of $1690 \mathrm{~m}$, is colonized by Bathymodiolus azoricus mussels as well as by Mirocaris fortunata shrimp assemblages (Comtet \& Desbruyères, 1998; Desbruyères et al., 2000; 2001; Cuvelier et al., 2009). After several monitoring/screening dives, 12 locations were chosen at various places on and around Eiffel Tower (Fig. 1), featuring various assemblages and possibly different physico-chemical conditions. A temporary "chain", equipped with autonomous temperature probes, was placed on each sampling location (Fig. 2).

\subsection{Faunal sampling}

The ROV Victor6000 was used to sample the fauna at each sampling site. First the temporary chain was removed, after which the mobile fauna on the area previously covered by the chain was sampled with the ROV suction sampler. Subsequently, the underlying faunal 
assemblages (on the same area as previously sampled with the suction sampler) were sampled with Victor's arm grab and put into separate sampling boxes. Finally, a second suction sample was taken on the bare surface in order to recover the remaining fauna. Surfaces sampled have been delineated on the faunal assemblages and sampling locations as presented in Fig. 2.

\subsection{Image analysis}

\subsubsection{Imagery collection and characteristics}

During all the dives, video imagery data was recorded by a 3-CCD camera (HYTEC, VSPN 3000) and a digital high definition still camera (Sony, Cybershot), mounted above the principal camera of the ROV. Pan, tilt and zoom were kept constant to the extent possible (i.e. not compromising manoeuvres from the ROV). All imagery data was digitally recorded on DVDs. Lighting was provided by 8 flood lights on a fixed bar at the front of the ROV, totalling $5 \mathrm{~kW}$.

For the image analysis, all imagery available (from the approach of the sampling site and the sampling itself) was used, comprising high-resolution photographs, video imagery and screen-stills. Still-images were used as templates to map the surface sampled and analyse the fauna within. Preference was given to the use of high-resolution images, which were mostly available for all sites, however when these were unavailable or unusable, screen-stills were used as a template for analyses. High-definition images had a resolution of 2048 x 1536 pixels while screen-stills were 696 x 576 pixels. Additional high-resolution photographs, featuring zoom-ins, different angles, alongside video imagery from different angles were used to study these sampling sites to reduce the visual distortion of the irregular hydrothermal

\subsubsection{Evaluation of sampled surfaces}

In order to allow comparisons between the different sampling sites, the surfaces sampled were measured with pixel-based image analysis software IPLAB Spectrum $\odot$ as described in Sarrazin et al. (1997) (Fig. 2). For this study, the twelve instrumented chains with links of $9 \mathrm{~cm}$ were used to set the calibration. Because the chains were removed before sampling the fauna, the length of a remarkable feature (mussel, rock) present in the digital photos taken before and after sampling was measured. This feature was then used to calibrate the post-sampling photo and the sampled surface was outlined manually. This was done for each sampling unit separately. In order to reduce the variability due to manual tracing, a mean 
details). To allow comparison between imagery and the faunal ground-truth samples, we restricted ourselves to analyse what was within these sampled surfaces.

\subsubsection{Biological data extraction and ground-truthing}

\section{Faunal composition and taxonomic richness}

High definition photographs as well as video footage were analysed to evaluate faunal abundances on the different sampling sites. Taxa were identified to the lowest taxonomic level possible, based on the imagery available. In order to allow comparison in faunal composition between imagery and corresponding faunal samples, organisms from the actual samples were assembled in similar higher taxonomic groups. Abundances were subject to parametric or non-parametric pair-wise testing between imagery and sampling, depending on the normality of the data. Besides this, taxonomic richness was compared between sampling and imagery. Both sample and site-based expected taxonomic richness were assessed by using rarefaction curves (Gotelli \& Colwell, 2001; Gauthier et al., 2010).

\section{Mussel lengths and biomass}

Mussel sizes were analysed on screen. The entire length of the animal was measured when possible but most often, only the width was measurable. In those cases, the lengths were estimated based on a strong relationship between widths and lengths ( $\mathrm{Y}=0.8438 \mathrm{x}-0.0241$, $\mathrm{R}^{2}=0.9519$, $\mathrm{n}=621$ ), as extracted from the ground-truth samples (Sarrazin et al., unpublished results). Using a paired t-test, mean mussel sizes as measured on-screen were compared with those from the corresponding ground-truth samples. The evaluation of the lengths also enabled the determination of biomass of mussels on imagery, based on the strong relationship linking shell length to biomass measures, also deduced from the corresponding ground-truth samples (Sarrazin et al., unpublished results). Based on this dataset, Ash Free Dry Weight (AFDW, $\mathrm{R}^{2}=0.9889$ ) and Wet Weight without shell (WWws, $\mathrm{R}^{2}=0.9892$ ) were calculated and used in the biomass estimations carried out here.

\subsubsection{Additional ecological factors based exclusively on imagery}

\section{Mussel valve opening}

The aperture of the shells (or valve gape) was also analysed as the number of mussels that had their valve opened, in order to assess the amount of individuals possibly displaying filtration activity, inhalation of sulphide-rich vent fluids, or gas exchange with the environment. 


\section{Microbial coverage}

The microbial cover was measured directly on-screen, by tracing the different surfaces covered by the white filamentous mats visible on the image. The surface coverage of the microbial mats was calculated as a mean of three measurements to assess the final microbial surface area (see Sarrazin et al. 1997 for the image analysis method).

\subsubsection{Observer's effect}

For the first six sampling units, an observer effect was evaluated. The imagery data were analysed by two scientists and differences between their observations were assessed.

213 Observations subject to observer effects' tests were (i) surfaces sampled, (ii) mussel densities, 214 (iii) mean mussel size, (iv) percentage of mussels with microbial cover and with opened valves and (v) abundance of associated fauna. Mean mussel size for C3 was only estimated by one observer, as mussels at this site were covered by microbial mats and single individuals were hard to discern. Differences were analysed with paired t-tests when values were normally distributed. If the normality assumption was still not met after transformation, a Wilcoxon test for paired samples, which is the non-parametric equivalent of the paired samples t-test, was carried out.

\section{$\underline{\text { 3. Results }}$}

223 3.1. Comparing data extraction from imagery with samples

All biological data extracted from the imagery (video and photo) are listed in Table 1. Faunal densities and abundances were assessed based on high-definition photographs and video footage from the twelve chain deployment sites. Species were grouped into higher level taxa, in order to avoid identification errors based on the imagery. Some species were identifiable to species level, e.g. Bathymodiolus azoricus and Segonzacia mesatlantica. For the others, we chose to group them into family levels or classes (Table 1). An overview of the ground-truth sample data (Sarrazin et al., unpublished results), corresponding in taxonomic level to those obtained with the video imagery, is also given (Table 1).

\subsubsection{Faunal composition and diversity}

Bathymodiolus azoricus mussels were the main constituent of the assemblages sampled, followed by Mirocaris fortunata shrimp. In order to allow ground-truthing, the same grouping in taxa was applied to the data originating from the gound-truth samples (Table 1). 
237 Generally, for polychaetes and gastropods and, to a lesser extent for B. azoricus and 238 alvinocaridid shrimps, a higher abundance was discernable in the ground-truth samples when compared to imagery (Fig. 3). This observation was very pronounced for the polychaetes and the gastropods (Fig. 3). Exceptions for mussels were C2, C6 and C8 and for shrimp C5, C8, C9 and C12 that featured higher densities on the imagery. There were no B. azoricus visible directly on the sampled surface of sampling unit C9 but they were observed in the surroundings (Fig. 2). These faunal abundances were tested pair-wise (Wilcoxon test) between sampling and imagery for each taxon and showed significant differences for mussels $(\mathrm{V}=72, \mathrm{p}$-value $=0.007)$, polychaetes $(\mathrm{V}=0, \mathrm{p}$-value $=0.004)$ and gastropods $(\mathrm{V}=0, \mathrm{p}$ value $=0.004)$ but no significant differences for shrimp $(\mathrm{V}=12, \mathrm{p}$-value $=0.13)$. Ophiuridae and Segonzacia crabs, on the other hand, showed higher abundances and were encountered more often on the imagery than in the samples, be it in a non-significant way ( $\mathrm{V}=30$, p-value $=0.10$ for the crabs and $\mathrm{V}=6, \mathrm{p}$-value $=0.17$ for the ophiurids).

Overall, when investigating taxonomic richness, several macrofaunal taxa present in the ground-truth samples were not found on the imagery. These include small-sized species belonging to polychaetes and gastropod taxa, but also pycnogonids, ostracods, actinids, halacarids, nematods, copepods, tanaids and amphipods. For all locations, the taxonomic richness is higher in the samples, than that recognised on the imagery. The maximum taxonomic richness for the imagery analyses was found at sampling units $\mathrm{C} 1$ and $\mathrm{C} 11$, where 6 different taxa were encountered. In the ground-truth samples, the highest taxonomic richness was found in $\mathrm{C} 11$ with a total of 14 macrofaunal taxa, followed by $\mathrm{C} 3$ with 13 taxa (Table 1). The lowest richness from the imagery was attributed to sampling unit C9 where only 2 taxa were observed on the imagery. In the samples, the lowest taxonomic richness was observed in C9 as well with 4 taxa (Table 1). The taxonomic richness as deduced from imagery compared to that from sampling was significantly different (paired t-test, $t=5.9699$, $\mathrm{df}=11$, $\mathrm{p}$-value $=0.00009$ ). Furthermore, an additional test (ANOVA) confirmed that the results obtained from sampling (S) and Imagery (I) are significantly different from each other i.e. that variation in taxonomic richness between $\mathrm{S}$ and $\mathrm{I}$ is larger than between the sampling locations $(\mathrm{F}=20.28, \mathrm{df}=1, \mathrm{p}=0.0002)$. However, there was a significant positive correlation between the taxonomic richness's from imagery and sampling $(\mathrm{t}=2.4654, \mathrm{df}=10$, $\mathrm{p}$ value $<0.05$ ), thus implying that they show similar tendencies. 
The sample-based rarefaction curves (Fig. 4) also showed that the expected taxon richness for discrete sampling was higher than that for imagery, clearly exhibiting the limits of imagery for estimating richness. Moreover, the curve of the imagery analyses seemed to reach an asymptote rather quickly while that of the sampling still did not yet stabilize for the number of samples investigated here, reinforcing the fact that video imagery is a rather weak estimator of overall species or taxon richness in these hydrothermal assemblages (Fig. 4).

\subsubsection{Mussel size and biomass}

Bathymodiolus azoricus mussels were visibly the most abundant species in the sampling units and were therefore subject to several additional analyses, such as size measurements and biomass estimations (Table 1). There was a difference in mean mussel size between sampling and imagery (paired t-test, $\mathrm{t}=-1.9922, \mathrm{df}=10, \mathrm{p}$-value $=0.074$ ) (Fig. 5). The biomass calculations were based on the existing significant relationship between size and biomass for the sampled individuals. No significant differences, not for Ash free Dry Weight (AFDW, $\mathrm{t}=-0.6634, \mathrm{df}=10, \mathrm{p}$-value=0.52), nor for Wet Weight without shell (WWws $\mathrm{t}=-$ 0.8894, $\mathrm{df}=10, \mathrm{p}$-value $=0.3947$ ) were observed between the sampled individuals and those estimated from the mussels measured on the video imagery.

\subsubsection{Valve openings}

The proportion of open mussels was also assessed as a percentage of all mussels present in the sampled area. These values varied between $3 \%$ and $85 \%$ on $\mathrm{C} 2$ and $\mathrm{C} 4$

\subsubsection{Microbial Cover}

Microbial cover was evaluated as the sampled surface covered by the microbial mats. It varied from $0.001 \mathrm{~m}^{2}$ to $0.032 \mathrm{~m}^{2}$ and no microbial mats were observed on sampling units C2, C7, C8, C9 and C10 (Table 1).

\subsection{Observer's effect}

For the first six sampling units ( $\mathrm{C} 1$ to $\mathrm{C6}$ ), two observers assessed the same parameters, independently from one another. Even though differences between the observers are noticeable (Fig. 6), no significant differences were revealed between the sampled surfaces 
percentage of mussels with their valve opened $(\mathrm{t}=0.9695, \mathrm{df}=5, \mathrm{p}$-value $=0.38)$. The densities of the associated fauna were systematically higher for Observer 1 than for Observer 2 but these differences were not significant (p-value>0.1, Fig. 6).

On the other hand, a significant difference for the mean mussel size estimations was revealed between the two observers $(t=-3.4232, \mathrm{df}=4, \mathrm{p}$-value $=0.027)$, which were systematically slightly higher for Observer 2 (Fig. 6). The mean mussel size of C3 was not taken into account in the statistical tests because it was only measured by one of the observers. The results also show that, with the exception of $\mathrm{C} 1$, the two observers encountered the same number of taxa on all sampling units (Fig. 6).

\section{$\underline{\text { 4. Discussion }}$}

\subsection{Biological data extraction}

\subsubsection{Faunal composition and diversity}

When comparing imagery and sampling, some distinct differences in observations tend to come out. For instance, crabs and ophiuroids are more abundant in the imagery data than in the samples, although non-significant. Such a trend could not be revealed for the shrimp. Nevertheless, we can conclude that assessing mobile faunal presence and/or abundance of some larger macrofaunal taxa is more accurate based on imagery than sampling, since mobile organisms tend to escape during sampling. On the other hand, the abundance of smaller organisms such as polychaetes, amphipods, copepods and gastropods, which tend to live in interstitial spaces between mussels (Van Dover \& Trask, 2000), or even inside the mussels' mantle cavity (e.g. the polynoid polychaete Branchipolynoe seepensis, Britayev et al., 2007), is almost impossible to evaluate on imagery and therefore explains the significant differences in abundances and taxonomic richness between imagery and samples. The same goes for younger and therefore smaller organisms. For example, there were no mussels visible in the image analyses from sampling unit C9 while 24 individuals were found in the samples (Sarrazin et al., unpublished results). These were not seen on imagery, most likely due to their

Taking all of the above into account, the diversity measures based on imagery represent a clear underestimation of the real diversity occurring on the Eiffel Tower hydrothermal edifice. At best, $71 \%$ of the real taxonomic diversity was assessed with imagery data while at worst, the estimation goes down to $23 \%$. This is confirmed by the sample-based 
smaller number of samples than the curve related to sampling, which does not level off.

339 Finally, as larger groups of taxa are considered, the taxonomic richness assessed is most likely 340 to only represent the minimum species richness of the Lucky Strike vent community 341 (Gauthier et al., 2010). However, the positive correlation in taxonomic richness between 342 sampling and imagery shows that researchers can reveal trends in taxonomic richness or 343 diversity occurring between the sampling sites based on imagery alone.

\subsubsection{Densities, size and biomass}

Densities (number of individuals $/ \mathrm{m}^{2}$ ) are extrapolated from the sampled surface estimations. This is an indispensable part for imagery analyses, but at the same time it represents the biggest challenge, as this comprises $2 \mathrm{D}$ analyses of $3 \mathrm{D}$ surfaces. In addition, mussels are known to stack up to several layers (Johnson et al., 1994) and offer secondary surfaces for associated organisms (Van Dover \& Trask, 2000). For example, limpets and other gastropods living on mussel shells and bare surfaces can be difficult to distinguish and identify because of their shape and colours (camouflage). This is also the main explanation for the significant differences in abundances/densities between imagery and sampling. On the other hand, the transport of faunal samples from the sampling units to sampling boxes can be tricky and can lead to loss of individuals, which, in several cases, can explain higher densities on imagery as it is the case for mussels on $\mathrm{C} 2, \mathrm{C} 6, \mathrm{C} 8$.

Mussel Sizes - Mean mussel sizes, as measured on imagery, do not show significant differences with the mussels measured in the lab. When investigating size-frequency distributions, it becomes clear that mussels with lengths between 15 and $60 \mathrm{~mm}$ are more predominant in the samples than on the imagery, while this size range should normally be visible on the imagery. Evidently, the mussel bed 3D structure is likely causing an underestimation of the visible abundance. Nonetheless, the lengths of the mussels measured on-screen can be considered a valid representation of the reality as shown for fish by Harvey et al. (2003).

Biomass - By measuring the mussel lengths on screen, biomass was calculated through the relationship established between the shell length and biomass from the groundtruth samples. No significant differences were revealed between the biomass assessed on imagery and that from the ground-truth samples. This implies that based on the lengths measured on-screen, our biomass estimations appear to be quite accurate, making the mussel 
length a good proxy for biomass estimations at larger scales. A similar exercise was carried out at Edison seamount (off Papua New Guinea), in which samples featuring vesicomyid clams were analysed by measuring lengths and widths and consequently using this biometric relationship to calculate biomass at a larger scale based on video-transects (Stecher et al., 2003). While hydrothermal vents are known for their high biomasses in the deep-sea (Sarrazin \& Juniper, 1999; Van Dover et al., 2001; Govenar et al., 2004; Dreyer et al., 2005), scientists are still struggling with assessing biomass efficiently and correctly in these remote habitats. This is mainly due to the irregular topography, the patchy distribution of vent animals and difficulties in quantitative sampling (Chevaldonné \& Jollivet, 1993). Based on the data presented here, the use of biometric relationships can thus be considered a powerful tool to estimate biomass on imagery from remote marine ecosystems. For now, we suggest that at vents it should be systematically validated with discrete samples taken simultaneously to the imagery until it is proven that it can be extrapolated in space and time.

\subsubsection{Valve opening}

The number of mussels with their valves opened was evaluated. This is only achievable through image analyses, which makes it an extra ecological parameter exclusive to imagery. Valve openings can be an indication of filtration activity in coastal bivalves and is often assessed through measurements of the gape observed between the valves (Riisgard et al., 2003; Maire et al., 2007). However, in the chemosynthetic vent ecosystem it can also be an indication of endosymbiont exposure to vent fluids or gas exchange. Despite the presence of a double endosymbiotic association with chemosynthetic bacteria in the gills of Bathymodiolus azoricus (Duperron et al., 2006), these mytilids are also capable of filterfeeding (Page et al., 1991; Tunnicliffe, 1991; Colaço et al., 2002) which may allow them to survive some time after vent disruption (Fisher, 1995; Copley et al., 1997). It was hypothesised that larger mussels would be more dependent on chemosynthesis, while smaller individuals would depend more on filter-feeding (Martins et al., 2008), but no such relationship could be revealed through our analyses. This could be due to the possibility that for the vent mussels, valve opening behaviour is linked with the general intake of energetic sources be it particles (filtration activity) and/or chemicals (chemosynthesis, respiration). Further research on valve gape activity of vent mussels would be interesting; in particular to evaluate potential links between valve openings and environmental conditions such as hydrothermal activity and hydrodynamic factors. The use of autonomous video camera from 
deep-sea observatories gives access to such data and could also enlighten us about the potential impacts of submersibles on the evaluation of animal behaviour in the deep-sea.

\subsubsection{Microbial cover}

The total surface covered by the microbial mats is also only quantifiable through imagery analyses (Cuvelier et al. 2011b) and is thus an asset to ground-truth sampling. Microbial mats are quite abundant in the vent environment but not much is known about their composition, or about the environmental conditions they thrive in. On Eiffel Tower, large areas covered by mussels are mat-free while other B. azoricus assemblages are completely covered (Cuvelier et al. 2009). A study by Crépeau et al. (2011) showed a highly diverse microbial community within the microbial mats at Lucky Strike, covering hydrothermal deposits and Bathymodiolus azoricus individuals. While the relationships between mussels and mats are still poorly understood, it does not appear to point to a negative one as mussel assemblages covered by microbial mats coexist with mussel assemblages free of microbial mats, both of them being healthy. A commensal relationship thus appears to be the most convincing scenario in which sulphur and methane oxidizers benefit from fluid dispersion by mussels and numerous heterotrophic microorganisms degrade the organic material released by the mussels (Crépeau et al. 2011).

\subsubsection{Observer effect?}

For most features tested (sampled surface, mussel densities, percentage of mussels with opened valves, densities of the associated fauna), no significant differences were found between the two observers. Only the mean mussel sizes were significantly different. This may be due to overall image quality or to the presence and thickness of microbial coverage (as seen on C3) which may render the basic calibration and/or measurements in general more difficult. A better training of the observers or a clarification of the method used (tutorial) may be considered to reduce such errors/bias. Automated recognition and contouring, using thresholds or pixel-based colour detection, could be helpful to resolve this problem. Additional issues with the image resolution and/or creation of shade casted by the ROV lights on the organisms could lead to different perceptions and measurements on the sampling units analysed.

\subsection{Imagery vs. Sampling}


Both methodologies appear to be indispensable and complementary one to another. Although imagery traditionally needs ground-truthing to corroborate what is seen on screen, it can be used self-sufficiently afterwards for a number of features, for example to investigate assemblage distribution and variations over time (Cuvelier et al., 2009; 2011a, b). Even to such an extent that, at vents, temporal variation studies are carried out almost solely based on imagery, as it is often the only long-term monitoring tool available. Since an increasing number of deep-sea MPA's will be created and more restrictions on sampling will be imposed, imagery can be a good alternative as it also allows in-depth ecological evaluations, whose value cannot be underestimated. Imagery also completes the data gathered by the samples with information on animal behaviour, fluid flow quantification and coverage of faunal assemblages or microbial mats (Table 2). All these factors contribute to a more profound knowledge and understanding of the vent environment which we cannot have based on sampling alone.

\section{$\underline{5 .}$ Conclusions and perspectives}

Based on our findings, several biological features deduced from imagery were confirmed to be accurate assessments of ground-truth samples. For instance, the mytilid biomass estimations based on on-screen length measurements were shown to be a valid representation of the sampled biomass and mussel lengths. Moreover, a couple of features appear to be more precise when analysed on imagery than when based on sampling. This is true for the presence and abundance of large mobile fauna such as crabs and ophiurids that can escape from sampling and also for the microbial coverage which can only be quantitatively evaluated on the imagery.

However, faunal composition, abundance and richness are clearly underestimated when limited to imagery, though taxonomic richness assessed in imagery was shown to reveal similar trends as the ground-truth samples. Nevertheless, sampling is required to correctly evaluate these important biological factors. Besides this, imagery analysis also has multiple assets, with several variables being exclusively available through imagery, such as behaviour, surface and microbial coverage, etc. Moreover, once the structure of the faunal assemblages is well characterized in a region, video imagery can be used to monitor community distribution, dynamics and temporal changes at large spatial scales.

Mean mussel size was the only factor for which the two observers showed significant differences. The development of a clearer protocol or the use of automated calculations could

471 help resolving the observed discrepancies. In the mean time, several scientific teams started 
developing software featuring automated techniques for imagery analysis for different marine habitats (Aguzzi et al., 2011; Teixido et al., 2011), including deep-sea hydrothermal vents (Aron et al., 2011). On the longer term and with the use of systematic approaches, imagery will represent an essential tool to evaluate the impacts of global warming and anthropogenic activity in the deep ocean. It should be used to help proposing management policies in these remote habitats.

\section{$\underline{\text { References }}$}

Aguzzi, J., Mànuel, A., Condal, F., Guillén, J, Nogueras, M., del Rio, J., Costa C., Menesatti, P., Puig, P., Sardà, F., Toma, D., Palanques, A., 2011. The new seafloor observatory (OBSEA) for remote and long-term coastal ecosystem monitoring. Sensors 11: 5850-5872.

Aron, M., Sarrazin, J., Sarradin, P.M., Mercier G., 2011. Analysing the temporal dynamics of hydrothermal ecosystems by using automated image processing tools. European Geophysical Union (EGU) Geophysical Research Abstracts Vol. 13, EGU2011-7653 April 2011.

Bates, A.E., Tunnicliffe, V., Lee, R.W., 2005. Role of thermal conditions in habitat selection by hydrothermal vent gastropods. Marine Ecology Progress Series 305, 1-15.

Britayev, T.A., Martin, D., Krylova, E.M., Von Cosel, R., Aksiuk, T.S., 2007. Life - history traits of the symbiotic scale - worm Branchipolynoe seepensis and its relationships with host mussels of the genus Bathymodiolus from hydrothermal vents. Marine Ecology-an Evolutionary Perspective 28, 36-48.

Chevaldonné, P., Jollivet, D., 1993. Videoscopic study of deep-sea hydrothermal vent alvinellid polychaete populations - biomass estimation and behavior. Marine Ecology Progress Series 95, 251-262.

Colaço, A., Dehairs, F., Desbruyères, D., 2002. Nutritional relations of deep-sea hydrothermal fields at the Mid-Atlantic Ridge: a stable isotope approach. Deep-Sea Research Part I Oceanographic Research Papers 49, 395-412.

Comtet, T., Desbruyères, D., 1998. Population structure and recruitment in mytilid bivalves from the Lucky Strike and Menez Gwen hydrothermal vent fields $\left(37^{\circ} 17^{\prime} \mathrm{N}\right.$ and $37^{\circ} 50^{\prime} \mathrm{N}$ on the Mid-Atlantic Ridge). Marine Ecology Progress Series 163, 165-177.

Copley, J.T.P., Tyler, P.A., Van Dover, C.L., Shultz, A., Dickson, P., Singh, S., Sulanowska, M., 1999. Subannual Temporal Variation in Faunal Distributions at the TAG Hydrothermal Mound (26o N, Mid-Atlantic Ridge). Marine Ecology 20, 291-306.

Copley, J.T.P., Jorgensen, P.B.K., Sohn, R.A., 2007a. Assessment of decadal-scale ecological change at a deep Mid-Atlantic hydrothermal vent and reproductive time-series in the shrimp Rimicaris exoculata. Journal of the Marine Biological Association UK 84, 859-867. 
Copley, J.T.P, Flint, H.C., Ferrero, T.J., Van Dover, C.L., 2007b. Diversity of meiofauna and free-living nematodes in mussel beds at hydrothermal vents on the northern and southern East

Cuvelier, D., Sarradin, P.-M., Sarrazin, J., Colaço, A., Copley, J.T., Desbruyères, D., Glover, A.G., Serrão Santos, R., Tyler, P.A., 2011a. Hydrothermal faunal assemblages and habitat characterisation at the Atlantic Eiffel Tower edifice (Lucky Strike vent field). Marine Ecology $32,243-255$.

Cuvelier, D., Sarrazin, J., Colaço, A., Copley, J.T., Glover, A.G., Tyler, P.A., Serrão Santos, R., Desbruyères, D., 2011b. Community dynamics over 14 years at the Eiffel Tower hydrothermal edifice on the Mid-Atlantic Ridge. Limnology \& Oceanography 56 (5), 16241640 .

Desbruyères, D., 1998. Temporal variations in the vent communities on the East Pacific Rise and Galapagos Spreading Centre: a review of present knowledge. Cahiers de Biologie Marine 39, $241-244$.

Desbruyères, D., Almeida, A., Biscoito, M., Comtet, T., Khripounoff, A., Le Bris, N., Sarradin, P.M., Segonzac, M., 2000. A review of the distribution of hydrothermal vent communities along the northern Mid-Atlantic Ridge: dispersal vs. environmental controls. Hydrobiologia 440, 201-216.

Desbruyères, D., Biscoito, M., Caprais, J.C., Colaco, A., Comtet, T., Crassous, P., Fouquet, Y., Khripounoff, A., Le Bris, N., Olu, K., Riso, R., Sarradin, P.M., Segonzac, M., Vangriesheim, A. (2001). Variations in deep-sea hydrothermal vent communities on the MidAtlantic Ridge near the Azores plateau. Deep-Sea Research part I - Oceanographic Research Papers 48, 1325-1346.

Devey, C.W., Fisher, C.R., Scott, S., 2007. Responsible science at hydrothermal vents. Oceanography 20 (1), 162-171.

Dreyer, J.C., Knick, K.E., Flickinger, W.B., Van Dover, C.L., 2005. Development of macrofaunal community structure in mussel beds on the northern East Pacific Rise. Marine Ecology Progress Series 302, 121-134.

Duperron, S., Bergin, C., Zielinski, F., Blazejak, A., Pernthaler, A., McKiness, Z.P., DeChaine, E., Cavanaugh, C.M., Dubilier, N., 2006. A dual symbiosis shared by two mussel species, Bathymodiolus azoricus and Bathymodiolus puteoserpentis (Bivalvia: Mytilidae), from hydrothermal vents along the northern Mid - Atlantic Ridge. Environmental Microbiology 8(8), 1441-1447. 
Fabri, M.-C., Bargain, A., Briand, P., Gebruk, A., Fouquet, Y., Morineaux, M., Desbruyères, D., 2011. The hydrothermal vent community of a new deep-sea field, Ashadze- $1,12^{\circ} 58^{\prime} \mathrm{N}$ on the Mid-Atlantic Ridge. Journal of the Marine Biological Association of the United Kingdom $91(1), 1-13$.

Fisher, C.R., 1995. Towards an appreciation of hydrothermal vent animals: their environment, physiological ecology and tissue stable isotope values. In: Seafloor Hydrothermal Systems: Physical, Chemical, Biological, and Geological Interactions. S.E. Humphris, R.A. Zierenberg, L.S. Mullineaux, and R.E. Thomson, (Eds.), American Geophysical Union Monograph Series 91, Washington, DC., pp 297-316.

Fustec, A., Desbruyères, D., Juniper, K. S., 1987. Deep-sea hydrothermal vent communities at $13^{\circ} \mathrm{N}$ on the East Pacific Rise: Microdistribution and temporal variations. Biological Oceanography 4(2), 121-164.

Gauthier, O., Sarrazin, J., Desbruyères, D., 2010. Measure and mis - measure of species diversity in deep - sea chemosynthetic communities. Marine Ecology Progress Series 402, 285-302.

Godet, L., Zelnio, K.A., Van Dover, C.L, 2010. Scientists as stakeholders in conservation of hydrothermal vents. Conservation Biology 25 (2), 214-222.

Gotelli, N.J., Colwell, R.K., 2001. Quantifying biodiversity: procedures and pitfalls in the measurement and comparison of species richness. Ecology Letters 4, 379-391.

Govenar, B., Freeman, M., Bergquist, D.C., Johnson, G.A., Fisher, C.R., 2004. Composition of a one year old Riftia pachyptila community following a clearance experiment: insight to succession patterns at deep-sea hydrothermal vents. Biological Bulletin 207, 177-182.

Grélon, D., Morineaux, M., Desrosiers, G., Juniper, S.K., 2006. Feeding and territorial behavior of Paralvinella sulfincola, a polychaete worm at deep-sea hydrothermal vents of the Northeast Pacific Ocean. Journal of Experimental Marine Biology and Ecology 329, 174-186.

Harvey, E., Cappo, M., Shortis, M., Robson, S., Buchanan, J., Speare, P., 2003. The accuracy and precision of underwater measurements of length and maximum body depth of southern bluefin tuna (Thunnus maccoyii) with a stereo-video camera system. Fisheries Research 63, 315-326.

Hessler, R.R., Smithey, W.M., Keller, C.H., 1985. Spatial and temporal variation of giant clams, tubeworms and mussels at deep-sea hydrothermal vents. Bulletin of the Biological Society of Washington 6, 411-428.

Hessler, R.R., Smithey, W.M., Boudrias, M.A., Keller, C.H., Lutz, R.A., Childress, J.J., 1988. Temporal change in megafauna at the Rose Garden hydrothermal vent (Galapagos Rift eastern tropical Pacific). Deep-Sea Research Part a - Oceanographic Research Papers 35, 613 

hydrothermal vent mussel communities - the deep-sea analogue to the intertidal zone. DeepSea Research Part Ioceanographic Research Papers 41, 993-1011.

617

618

619

620

621

622

623

624

625

626

627

628

629

630

631

632

633

634

635

636

637

638

639

640

641

642

643

644

645

646

647

648

649

650

651

652

653

654

655

656

657

658

659

660

661

662

663

Johnson, S.B., Young, C.R., Jones, W.J., Warén, A., Vrijenhoek R.C., 2006. Migration, Isolation, and Speciation of Hydrothermal Vent Limpets (Gastropoda; Lepetodrilidae) Across the Blanco Transform Fault. Biological Bulletin 210, 140-157.

Juniper, S.K., Sarrazin, J., Grehan, A., 1998. Remote sensing of organism density and biomass at hydrothermal vents. Cahiers de Biologie Marine 39, 245-247.

Khripounoff, A., Comtet, T., Vangriesheim, A., Crassous, P., 2000. Near-bottom biological and mineral particle flux in the Lucky Strike hydrothermal vent area (Mid-Atlantic Ridge). Journal of Marine Systems 25, 101-118.

Khripounoff, A., Vangriesheim, A., Crassous, P., Segonzac, M., Lafon, V., Waren, A., 2008.

Temporal variation of currents, particulate flux and organism supply at two deep-sea hydrothermal fields of the Azores Triple Junction. Deep-Sea Research Part I - Oceanographic Research Papers 55, 532-551.

Magorrian, B.H., Service, M., 1998. Analysis of underwater visual data to identify the impact of physical disturbance on horse mussel (Modiolus modiolus) beds. Marine Pollution Bulletin 36: 354-359.

Maire, O., Amouroux, J.M., Duchêne, J.C., Grémare, A., 2007. Relationship between filtration activity and food availability in the Mediterranean mussel Mytilus galloprovincialis. Marine Biology 152, 1293-1307.

Marcus, J., Tunnicliffe, V., Butterfield, D., 2009. Post-eruption succession of macrofaunal communities at diffuse flow hydrothermal vents on Axial Volcano, Juan de Fuca Ridge, Northeast Pacific. Deep-Sea Research part II - Topical Studies in Oceanography 56, 15861598.

Martins, I., Colaço, A., Dando, P.R., Martins, I., Desbruyères, D., Sarradin, P.M., Marques, J.C., Serrao Santos, R., 2008. Size-dependent variations on the nutritional pathway of Bathymodiolus azoricus demonstrated by a C-flux model. Ecological Modelling 217, 59-71.

Nees, H.S., Moore, T.S., Mullaugh, K.M., Holyoke, R.R., Janzen, C.P., Ma, S., Metzger, E., Waite, T.J., Yücel, M., Lutz ,R.A., Shank, T.M., Vetriani, C., Nuzzio, D.B., Luther III, G.W., 2008. Hydrothermal vent mussel habitat chemistry, pre- and post-eruption at $9^{\circ} 50^{\prime}$ North on the East Pacific Rise. Journal of Shellfish Research 27(1), 169-175.

Ninio, R., Meekan, M., Done, T. and Sweatman, H., 2000. Temporal patterns in coral assemblages on the Great Barrier Reef from local to large spatial scales. Marine EcologyProgress Series 194, 65-74.

Norris, J.G., Wyllie-Echeverria, S., Mumford, T., Bailey, A., Turner, T., 1997. Estimating basal area coverage of subtidal seagrass beds using underwater videography. Aquatic Botany 58, 269-287. 
Official Journal of the European Union L 344, 2009. Commission decision of 22 December 2009 on adopting, pursuant to Council Directive 92/43/EEC, a second updated list of sites of Community importance for the Macaronesian biogeographical region (notified under document C(2009) 10414) (2009/1001/EU), 46-55

Page, H.M., Fialamedioni, A., Fisher, C.R., Childress, J.J., 1991. Experimental - evidence for filterfeeding by the hydrothermal vent mussel, Bathymodiolus thermophilus. Deep - Sea

Podowski, E.L., Moore, T.S., Zelnio, K.A., Luther, III G.W., Fisher, C.R., 2009. Distribution of diffuse flow megafauna in two sites on the Eastern Lau Spreading Center, Tonga. Deep Sea Research I - Oceanographic Research Papers 56, 2041-2056.

Ramondenc, P., Germanovich, L.N., VonDamm, K.L., Lowell, R.P., 2006. The first measurements of hydrothermal heat output at $9^{\circ} 50^{\prime} \mathrm{N}$, East Pacific Rise. Earth Planet. Sci. Lett. 245(3-4), 487.

Riisgard, H.U., Kittner, C., Seerup, D.F., 2003. Regulation of opening state and filtration rate in filter-feeding bivalves (Cardium edule, Mytilus edulis, Mya arena) in response to low algal concentration. Journal of Experimental Marine Biology and Ecology 284, 105-127.

Santos, R.S., Colaço, A., Christiansen, S. (Eds.) 2003. Planning the management of deep-sea hydrothermal vent fields MPAs in the Azores Triple Junction (Workshop proceedings). Arquipélago - Life and Marine Sciences, Supplement 4: xii + 70pp.

Sarrazin, J., Juniper, S.K., 1999. Biological characteristics of a hydrothermal edifice mosaic community. Marine Ecology Progress Series 185, 1 - 19.

Sarrazin, J., Robigou, V., Juniper, S. K., Delaney, J. R., 1997. Biological and geological dynamics over four years on a high - temperature sulfide structure at the Juan de Fuca Ridge Hydrothermal Observatory. Marine EcologyProgress Series 153, 5 - 24.

Sarrazin, J., Levesque, C., Juniper, S.K., Tivey, M.K., 2002. Mosaic community dynamics on Juan de Fuca Ridge sulfide edifices: Substratum, temperature and implications for trophic structure. Cahiers De Biologie Marine 43, 275 - 279.

Sarrazin, J., Walter, C., Sarradin, P.M., Brind'Amour, A., Desbruyères, D., Briand, P., Fabri, M.C., Van Gaever, S., Vanreusel, A., Bachraty, C., Thiébaut, E., 2006. Community structure and temperature dynamics within a mussel community on the southern East Pacific Rise. Cahiers de Biologie Marine 47, 483-490.

Sarrazin, J., Rodier, P., Tivey, M.K., Singh, H., Shultz, A., Sarradin, P.M., 2009. A dual sensor device to estimate fluid flow velocity at diffuse hydrothermal vents. Deep Sea Research Part I - Oceanographic Research Papers 56, 2065-2074.

Shank, T.M., Fornari, D.J., Von Damm, K.L., Lilley, M.D., Haymon, R.M., Lutz, R.A., 1998. Temporal and spatial patterns of biological community development at nascent deep-sea hydrothermal vent (9 $9^{\circ} 0^{\prime} \mathrm{N}$, East Pacific Rise). Deep - Sea Research part II - Topical Studies in Oceanography 45, 465-515. 
Shank, T., Fornari, D.J., Yoerger, D.R., Humphris, S.E., Bradley, A.L., Hammond, S., Lupton, J.E., Scheirer, D., Collier, R., Reysenbach, A.L., Ding, K., Seyfried, W., Butterfield, D.A., Olson, E.J., Lilley, M.D., Ward, M.E., Eisen, J.A., 2003. Deep submergence synergy: Alvin and Abe explore the Galapagos Rift at $86^{\circ} \mathrm{W}$. EOS, Transactions, American Geophysical Union 84, 425-440.

Stecher, J., Tunnicliffe, V., Turkay, M., 2003. Population characteristics of abundant bivalves (Mollusca, Vesicomyidae) at a sulphide-rich seafloor site near Lihir Island, Papua New Guinea. Canadian Journal of Zoology-Revue Canadienne De Zoologie 81: 1815-1824.

Teixido, N., Albajes-Eizagirre, A., Bolbo, D., Le Hir, E., Demestre, M., Garrabou, J., Guigues, L., Gili, J-M., Piera. J., Prelot, T., Soria-Frisch, A., 2011. Hierarchical segmentation-based software for cover classification analyses of seabed images (Seascape). Marine ecology Progress Series 431, 45-53.

Thiébaut, E., Huther, X., Shillito, B., Jollivet, D., Gaill, F., 2002. Spatial and temporal variations of recruitment in the tube worm Riftia pachyptila on the East Pacific Rise $\left(9^{\circ} 50^{\prime} \mathrm{N}\right.$ and $\left.13^{\circ} \mathrm{N}\right)$. Marine ecology Progress Series 234, 147-157.

Tsurumi, M., Tunnicliffe, V., 2001. Characteristics of a hydrothermal vent assemblage on a volcanically active segment of Juan de Fuca Ridge, Northeast Pacific. Canadian Journal of Fisheries and Aquatic Sciences 58, 530 - 542.

Tunnicliffe, V., 1990. Observations on the effects of sampling on hydrothermal vent habitat and fauna of Axial Seamount, Juan-de-Fuca Ridge. Journal of Geophysical Research - Solid Earth and Planets 95, 12961 - 12966.

Tunnicliffe, V., 1991. The biology of hydrothermal vents - Ecology and evolution. Oceanography and Marine Biology 29, 319-407.

Tunnicliffe, V., Embley, R.W., Holden, J.F., Butterfield, D.A., Massoth, G.J., Juniper S.K., 1997. Biological colonization of new hydrothermal vents following an eruption on Juan De Fuca Ridge. Deep - Sea Research Part I - Oceanographic Research Papers 44, 1627 - 1644.

Tyler, P., German, C., Tunnicliffe, V., 2005. Biologists do not pose a threat to deep-sea vents. Nature 434, 18-18.

Urcuyo, I.A., Massoth, G., Macdonald, I., Fisher, C.R., 1998. In situ growth of the vestimentiferan Ridgeia piscesae living in highly diffuse vents in the main endeavour segment of the Juan de Fuca Ridge. Cahiers de Biologie Marine 39, 267-270.

Urcuyo, I.A., Massoth, G.J., Julian, D., Fisher, C.R., 2003. Habitat, growth and physiological ecology of a basaltic community of Ridgeia piscesae from the Juan de Fuca Ridge. Deep-Sea Research Part I - Oceanographic Research Papers 50, 763-780.

Van Dover, C.L., Trask, J.L., 2000. Diversity at deep-sea hydrothermal vent and intertidal mussel beds. Marine Ecology Progress Series 195, 169-178. 
Van Dover, C.L., Humphris, S.E., Fornari D., Cavanaugh C.M., Collier R., Goffredi S.K.,

763 Hashimoto J., Lilley M.D., Reysenbach A.L., Shank T.M., Von Damm K.L., Banta A.,

764 Gallant R.M., Götz D., Green D., Hall J., Harmer T. L., Hurtado L. A., Johnson P., McKiness

765 Z.P., Meredith C., Olson E., Pan I.L., Turnipseed M., Won Y., Young III C.R., Vrijenhoek

766 R.C., 2001. Biogeography and Ecological Setting of Indian Ocean Hydrothermal Vents.

767 SCIENCE VOL 294: 818-823

Zekely, J., Van Dover, C.L., Nemeschkal, H., Bright, M., 2006. Hydrothermal vent the East Pacific Rise. Deep-Sea Research Part I - Oceanographic Research Papers 53, 13631378. 
Table 1. Overview of the biological data extraction based on imagery compared to that from sampling for corresponding taxa. The estimated size of the surface sampled as well as the densities of the visible fauna, mussel size and biomass, valve openings and microbial mat covering are given. *contains macrofaunal taxa that were not detectable on imagery and are thus not listed in the table. The mean temperature (with standard deviation) on each sampling unit was measured and was added for information purposes solely.

\begin{tabular}{|c|c|c|c|c|c|c|c|c|c|c|c|c|}
\hline Chains & C1 & C2 & C3 & C4 & C5 & C6 & C7 & C8 & C9 & C10 & C11 & C12 \\
\hline Surface sampled $\left(m^{2}\right)$ & $0.062 \pm 0.004$ & $0.070 \pm 0.012$ & $0.082 \pm 0.00$ & $0.049 \pm 0.001$ & $0.049 \pm 0.004$ & $0.077 \pm 0.007$ & $0.01 \pm 0.004$ & $0.028 \pm 0.002$ & $0.013 \pm 0.003$ & $0.061 \pm 0.006$ & $0.033 \pm 0.002$ & $0.032 \pm 0.002$ \\
\hline \multicolumn{13}{|l|}{ Densities (ind/m²) } \\
\hline $\begin{array}{l}\text { Bathymodiolus azoricus } \\
\text { Alvinocarididae } \\
\text { Segonzacia mesatlantica } \\
\text { Polychaeta } \\
\text { Ophiuridae } \\
\text { Gastropoda } \\
\text { From sampling units }\end{array}$ & $\begin{array}{c}2226 \\
177 \\
32 \\
48 \\
16 \\
387\end{array}$ & $\begin{array}{c}1029 \\
529 \\
29 \\
0 \\
0 \\
0\end{array}$ & $\begin{array}{c}1098 \\
207 \\
24 \\
0 \\
0 \\
0\end{array}$ & $\begin{array}{c}1918 \\
449 \\
20 \\
20 \\
0 \\
224\end{array}$ & $\begin{array}{c}4592 \\
41 \\
0 \\
20 \\
0 \\
204\end{array}$ & $\begin{array}{c}883 \\
338 \\
104 \\
0 \\
0 \\
0\end{array}$ & $\begin{array}{c}700 \\
7900 \\
700 \\
0 \\
0 \\
400\end{array}$ & $\begin{array}{c}536 \\
3536 \\
107 \\
0 \\
0 \\
0\end{array}$ & $\begin{array}{c}0 \\
462 \\
0 \\
0 \\
0 \\
923\end{array}$ & $\begin{array}{c}1246 \\
1164 \\
16 \\
0 \\
0 \\
0\end{array}$ & $\begin{array}{c}1727 \\
697 \\
152 \\
30 \\
61 \\
909\end{array}$ & $\begin{array}{c}3938 \\
656 \\
31 \\
31 \\
125 \\
0\end{array}$ \\
\hline $\begin{array}{l}\text { Bathymodiolus azoricus } \\
\text { Alvinocarididae } \\
\text { Segonzacia mesatlantica } \\
\text { Polychaeta } \\
\text { Ophiuridae } \\
\text { Gastropoda }\end{array}$ & $\begin{array}{c}5484 \\
323 \\
0 \\
5661 \\
0 \\
2516 \\
\end{array}$ & $\begin{array}{c}857 \\
1743 \\
71 \\
1000 \\
0 \\
43 \\
\end{array}$ & $\begin{array}{c}2049 \\
573 \\
12 \\
4341 \\
0 \\
610 \\
\end{array}$ & $\begin{array}{c}3776 \\
449 \\
0 \\
8592 \\
0 \\
796 \\
\end{array}$ & $\begin{array}{c}7857 \\
0 \\
0 \\
9041 \\
0 \\
1143 \\
\end{array}$ & $\begin{array}{c}792 \\
1338 \\
39 \\
403 \\
0 \\
26 \\
\end{array}$ & $\begin{array}{c}1200 \\
10900 \\
0 \\
500 \\
0 \\
1300 \\
\end{array}$ & $\begin{array}{c}214 \\
3500 \\
107 \\
250 \\
0 \\
143 \\
\end{array}$ & $\begin{array}{c}7077 \\
0 \\
0 \\
0 \\
0 \\
3154 \\
\end{array}$ & $\begin{array}{c}1475 \\
1426 \\
0 \\
1197 \\
0 \\
0 \\
\end{array}$ & $\begin{array}{c}4939 \\
697 \\
152 \\
6242 \\
30 \\
4485\end{array}$ & $\begin{array}{c}8500 \\
125 \\
0 \\
13469 \\
63 \\
1031 \\
\end{array}$ \\
\hline \multicolumn{13}{|l|}{ Macrofaunal taxon richness } \\
\hline $\begin{array}{l}\text { From Imagery } \\
\text { From sampling units * }\end{array}$ & $\begin{array}{c}6 \\
10\end{array}$ & $\begin{array}{l}3 \\
7\end{array}$ & $\begin{array}{c}3 \\
13\end{array}$ & $\begin{array}{l}5 \\
7\end{array}$ & $\begin{array}{l}4 \\
9\end{array}$ & $\begin{array}{l}3 \\
7\end{array}$ & $\begin{array}{l}4 \\
6\end{array}$ & $\begin{array}{l}3 \\
7\end{array}$ & $\begin{array}{l}2 \\
4\end{array}$ & $\begin{array}{l}3 \\
5\end{array}$ & $\begin{array}{c}6 \\
14\end{array}$ & $\begin{array}{c}5 \\
12\end{array}$ \\
\hline \multicolumn{13}{|l|}{ Mussels } \\
\hline $\begin{array}{l}\text { Mean Mussel size }(\mathrm{mm}) \\
\text { Mussel AFDW }\left(\mathrm{kg} / \mathrm{m}^{2}\right) \\
\text { Mussel WWws }\left(\mathrm{kg} / \mathrm{m}^{2}\right) \\
\text { Valve openings \% }\end{array}$ & $\begin{array}{c}36.99 \pm 8.91 \\
0.54 \\
3.67 \\
24.64\end{array}$ & \begin{tabular}{|c|}
$70.96 \pm 14.22$ \\
0.89 \\
7.09 \\
19.44
\end{tabular} & $\begin{array}{c}47.84 \pm 13.85 \\
0.42 \\
3.04 \\
4.44\end{array}$ & \begin{tabular}{|c}
$42.36 \pm 15.51$ \\
1.07 \\
7.54 \\
85.11
\end{tabular} & $\begin{array}{c}29.36 \pm 11.36 \\
0.48 \\
3.12 \\
67.11\end{array}$ & $\begin{array}{c}57.32 \pm 9.47 \\
0.49 \\
3.73 \\
32.35\end{array}$ & $\begin{array}{c}46.29 \pm 5.25 \\
0.31 \\
2.21 \\
14.29\end{array}$ & $\begin{array}{c}73.1 \pm 15.62 \\
0.59 \\
4.73 \\
40.00\end{array}$ & $\begin{array}{l}N / A \\
N / A \\
N / A \\
N / A\end{array}$ & \begin{tabular}{|c|}
$60.28 \pm 14.30$ \\
1.74 \\
13.34 \\
11.84
\end{tabular} & $\begin{array}{c}45.21 \pm 12.72 \\
0.58 \\
4.18 \\
42.11\end{array}$ & $\begin{array}{c}42.08 \pm 12.54 \\
\quad 1.06 \\
7.43 \\
3.17\end{array}$ \\
\hline $\begin{array}{l}\text { Microbial surface cover }\left(\mathrm{m}^{2}\right) \\
\text { Microbial surface cover \% }\end{array}$ & $\begin{array}{c}0.009 \pm 0.00 \\
15.0\end{array}$ & $\begin{array}{c}0.00 \pm 0.00 \\
0.0\end{array}$ & $\begin{array}{c}0.032 \pm 0.002 \\
38.7\end{array}$ & $\begin{array}{c}0.012 \pm 0.002 \\
23.4\end{array}$ & $\begin{array}{c}0.013 \pm 0.001 \\
27.3\end{array}$ & $\begin{array}{c}0.009 \pm 0.00 \\
11.3\end{array}$ & $\begin{array}{c}0.00 \pm 0.00 \\
0.0\end{array}$ & $\begin{array}{c}0.00 \pm 0.00 \\
0.0\end{array}$ & $\begin{array}{c}0.00 \pm 0.00 \\
0.0\end{array}$ & $\begin{array}{c}0.00 \pm 0.00 \\
0.0\end{array}$ & $\begin{array}{c}0.001 \pm 0.00 \\
3.8\end{array}$ & $\begin{array}{c}0.012 \pm 0.00 \\
39.5\end{array}$ \\
\hline Temperature $\left({ }^{\circ} \mathrm{C}\right)$ & $4.91 \pm 0.47$ & $6.50 \pm 1.66$ & $5.35 \pm 0.33$ & $5.67 \pm 0.50$ & $5.11 \pm 0.48$ & $6.04 \pm 0.59$ & $5.39 \pm 0.30$ & $7.49 \pm 1.54$ & $4.79 \pm 0.12$ & $8.79 \pm 2.71$ & $4.85 \pm 0.26$ & $4.80 \pm 0.33$ \\
\hline
\end{tabular}


Table 2. Overview of ecological factors that can be quantitatively assessed based on imagery and sampling at hydrothermal vents. A selection of two recent publications is given as example, with a preference for the MAR regions. This table is an illustration for the differences, advantages and disadvantages of both sampling and imagery, not a review/overview of all literature/examples available. $\mathrm{P}$ indicates when imagery was found to be a poor estimator of the proposed variable in the present study. * are references not from the MAR region

\begin{tabular}{|c|c|c|c|}
\hline Imagery & refs & Sampling & refs \\
\hline \multicolumn{4}{|l|}{ Faunal composition and diversity } \\
\hline $\begin{array}{l}\text { Larger }(>1 \mathrm{~cm}) \text { dominant macrofauna } \\
\text { abundances }(P)\end{array}$ & this study & $\begin{array}{l}\text { Including the smaller faunal fraction such } \\
\text { as meiofauna, densities for all fractions }\end{array}$ & $\begin{array}{l}\text { Sarrazin et al., 2006*, Zekeley et } \\
\text { al., 2006; Copley et al, 2007b* }\end{array}$ \\
\hline Faunal assemblage distribution & $\begin{array}{l}\text { Cuvelier et al;, 2009, Podowski et } \\
\text { al., 2009* }\end{array}$ & / & \\
\hline Diversity $(P)$ & this study & Diversity & $\begin{array}{l}\text { Van Dover \& Trask, 2000; Tsurumi } \\
200^{\star} \text {, Sarrazin et al., 2006* }\end{array}$ \\
\hline Biomass & $\begin{array}{l}\text { Chevaldonné \& Jollivet, } 1993^{\star} \text {; } \\
\text { Stecher et al., } 2003^{*} \text {, this study }\end{array}$ & Biomass & $\begin{array}{l}\text { Govenar et al., 2004*; Dreyer et al., } \\
2005^{\star}\end{array}$ \\
\hline \multicolumn{4}{|l|}{ Behaviour and interactions } \\
\hline Valve opening for mussels & $\begin{array}{l}\text { Maire et al., } 2007^{*}(\text { non-vent), this } \\
\text { study }\end{array}$ & I & \\
\hline Retraction-expansion rates for tubeworms & $\begin{array}{l}\text { Tunnicliffe et al.,1990*, } \\
\text { Chevaldonné \& Jollivet, } 1993^{\star}\end{array}$ & / & \\
\hline Growth & $\begin{array}{l}\text { Urcuyo et al., } 1998^{*} \text {, Urcuyo et al., } \\
2003^{*}\end{array}$ & $\begin{array}{l}\text { Length-Frequency distributions to define } \\
\text { cohorts/classes }\end{array}$ & $\begin{array}{l}\text { Comtet \& Desbruyères, } 1998, \\
\text { Thiébaut et al., } 2002^{*}\end{array}$ \\
\hline Movements/Locomotion & $\begin{array}{l}\text { Bates et al., } 2005^{*} ; \text { Grélon et al., } \\
2006^{*}\end{array}$ & l & \\
\hline \multicolumn{4}{|l|}{ Coverage } \\
\hline Faunal coverage and surface estimations & $\begin{array}{l}\text { Sarrazin et al., } 1997^{*} \text {, Cuvelier et al., } \\
2009,2011 b\end{array}$ & / & \\
\hline Microbial mats & Cuvelier et al., 2011b, this study & / & \\
\hline \multicolumn{4}{|l|}{ Environmental variables/hydrothermal activity } \\
\hline Fluid flow debit & this study, Sarrazin et al 2009 & Fluid flow debit & $\begin{array}{l}\text { Ramondenc et al., 2006*; Sarrazin } \\
\text { et al } 2009\end{array}$ \\
\hline Local currents & this study & Large-scale currents & Khripounoff et al., 2000; 2008 \\
\hline Fluid relocation and re/de-activation & $\begin{array}{l}\text { Copley et al., 1999; Cuvelier et al., } \\
2011 \text { b }\end{array}$ & l & \\
\hline \multicolumn{4}{|l|}{ Temporal variations } \\
\hline Long-term variations of faunal distribution & $\begin{array}{l}\text { Shank et al. 1998*; Copley et al., } \\
\text { 2007a; Cuvelier et al., 2011b }\end{array}$ & Long-term variations in faunal samples & $\begin{array}{l}\text { Johnson et al., 2006*, Copley et al., } \\
\text { 2007a }\end{array}$ \\
\hline $\begin{array}{l}\text { Short-term variations of communities } \\
\text { (time lapse) }\end{array}$ & $\begin{array}{l}\text { Tunnicliffe et al., } 1990^{*} \text {; Copley et } \\
\text { al;, } 1999\end{array}$ & & \\
\hline
\end{tabular}




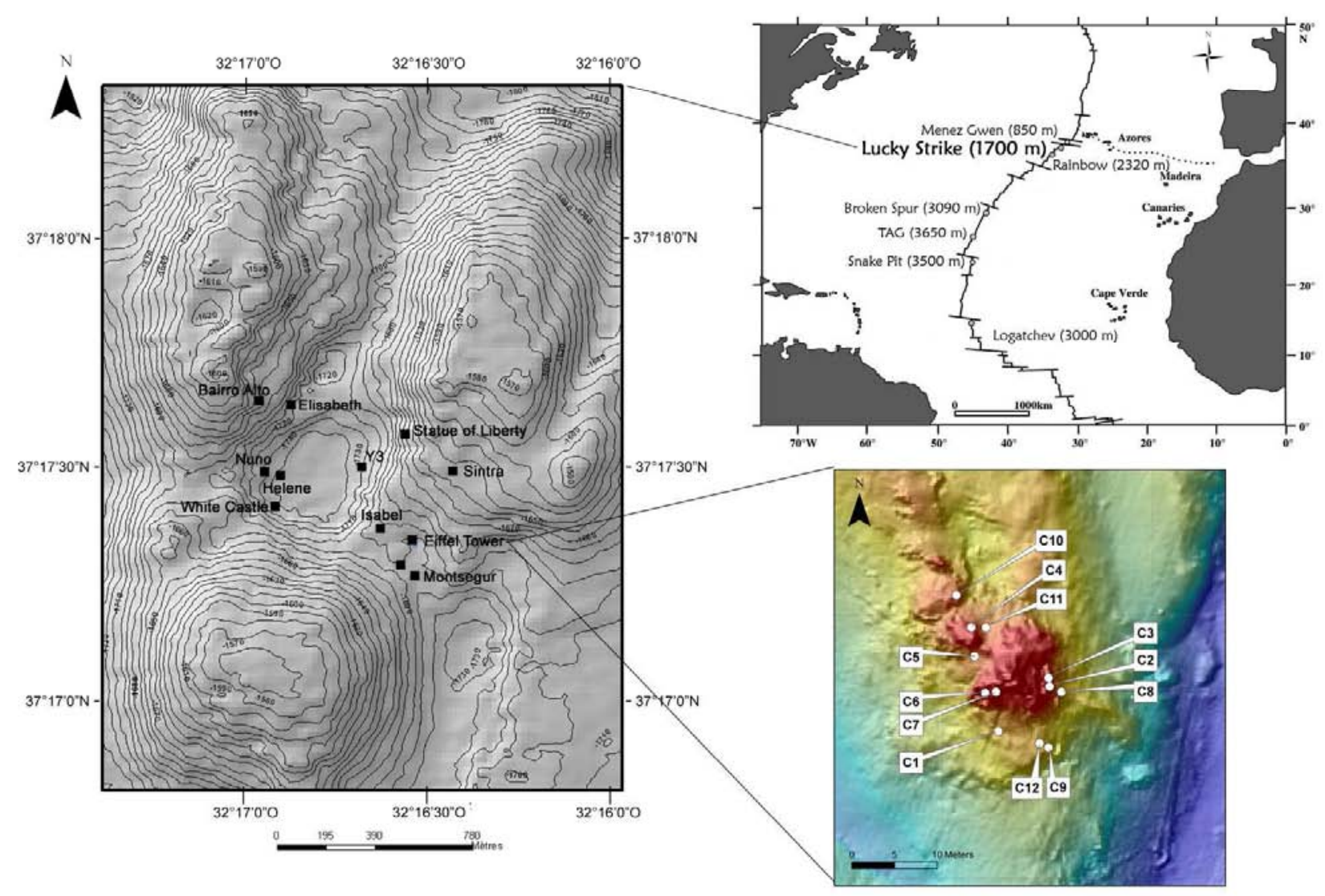

Fig. 1. Localisation of the Lucky Strike vent field along the Mid-Atlantic Ridge with an overview of the vent field and its bathymetry. In detail, a map of the Eiffel Tower edifice is shown with the locations of the 12 instrumented chains deployed during the MoMARETO cruise in 2006 on the Mid-Atlantic Ridge. 

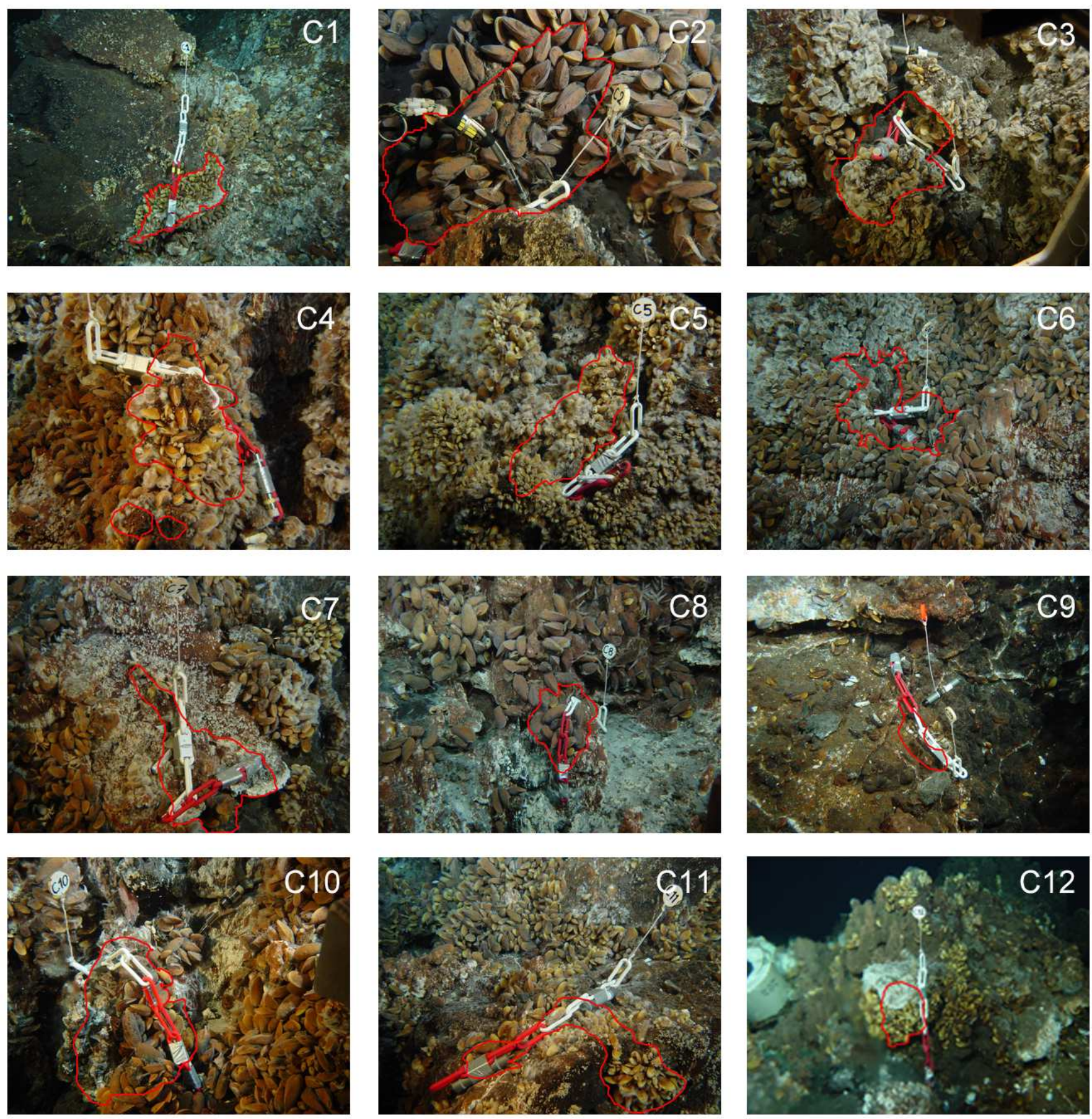

Fig. 2. Overview of the 12 instrumented chains (sampling units) and the delineation of the surface sampled, showing the assemblages and the habitats. Each link of the chain is $9 \mathrm{~cm}$ long. $\mathrm{C} 12$ is a bit blurry due to rising shimmering water in front of the camera lens. 

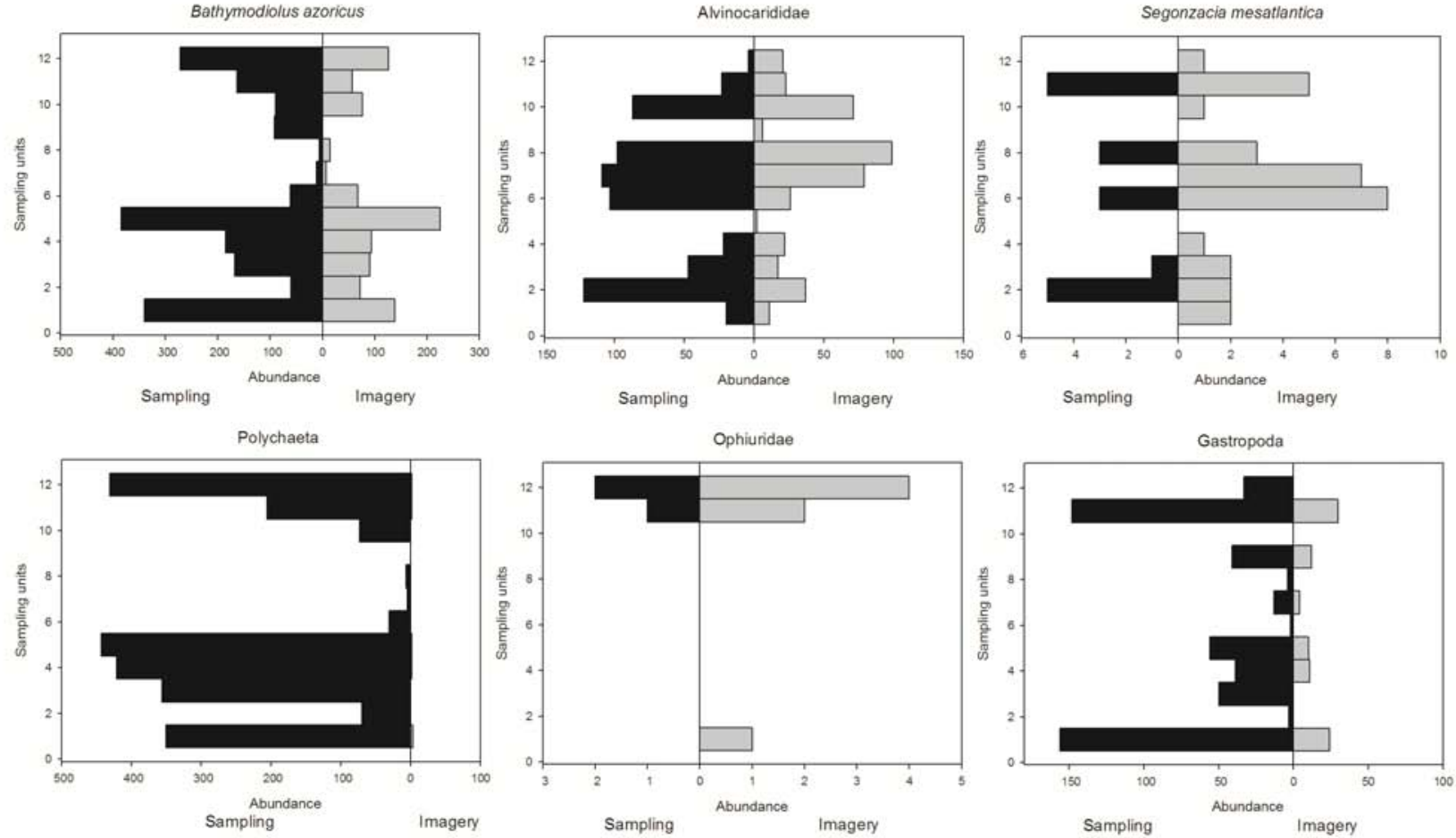

Fig. 3. Faunal abundances as identified on discrete sampling (left=black) and imagery (right=grey) 


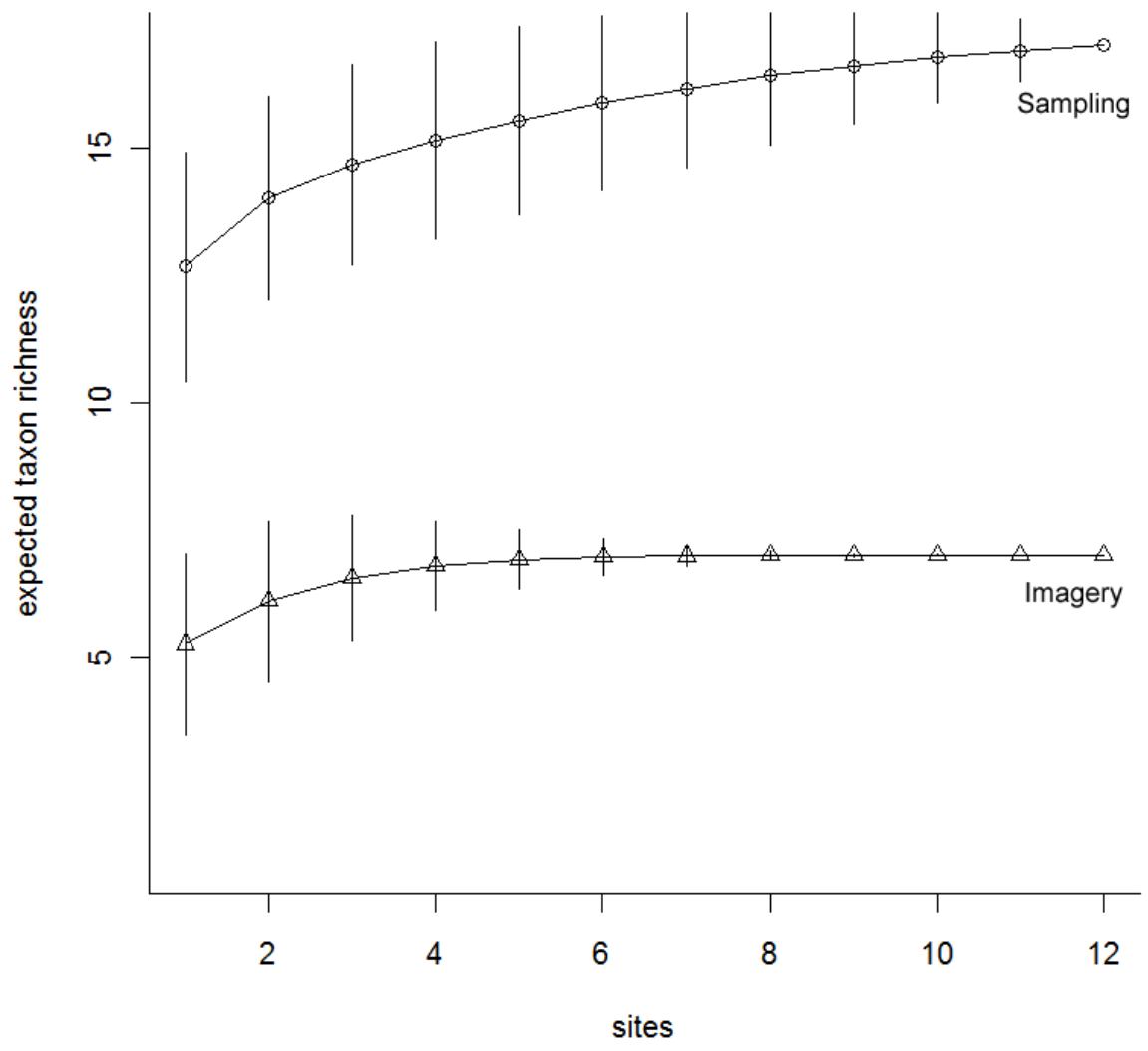

Fig. 4. Rarefaction curves displaying the expected taxonomic richness in the sampling units and imagery. 

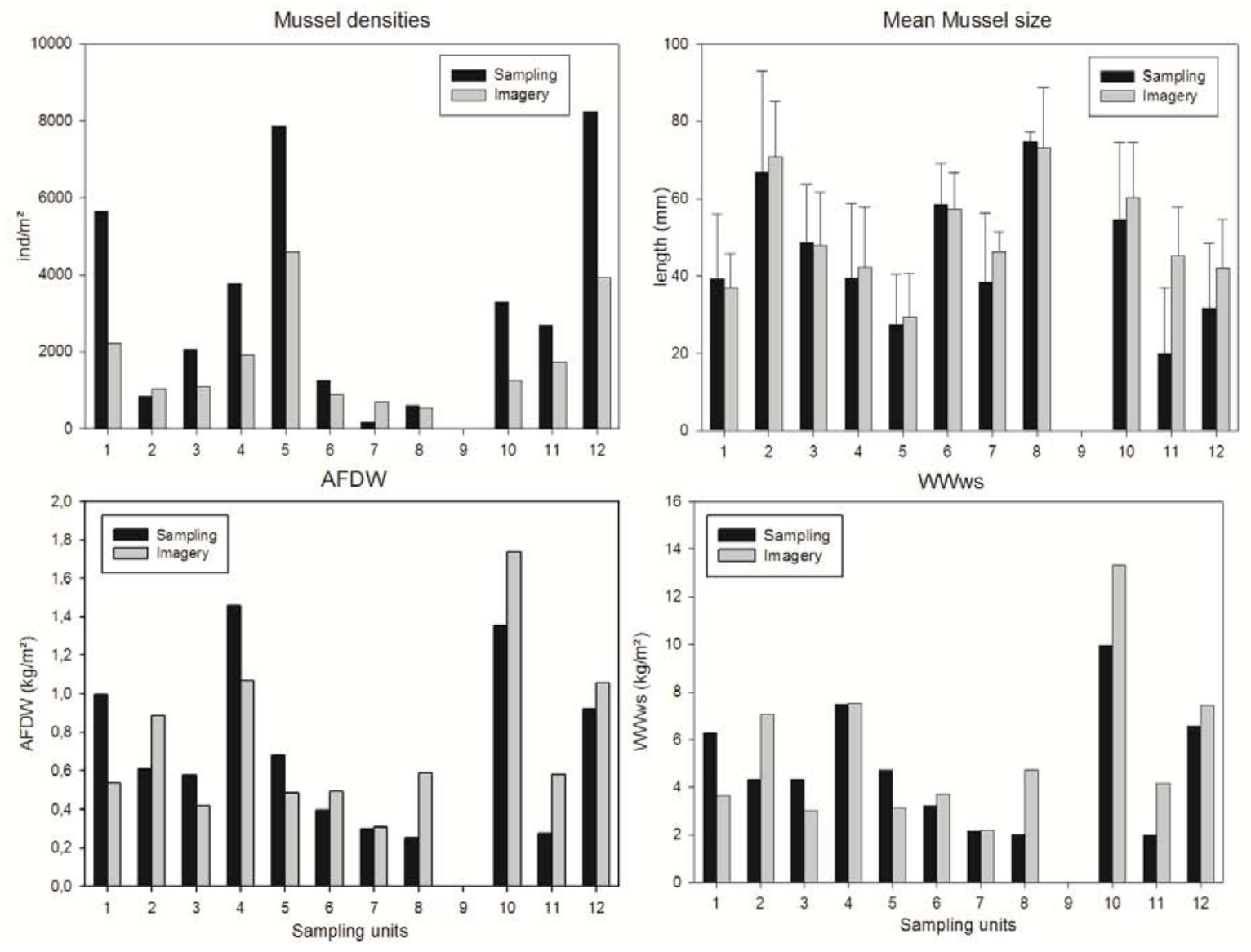

Fig. 5. Comparison of Bathymodiolus azoricus mussel densities, mean sizes and biomass (wet weight - WWws - and ash free dry weight - ASFDW) between the samples and video imagery. 

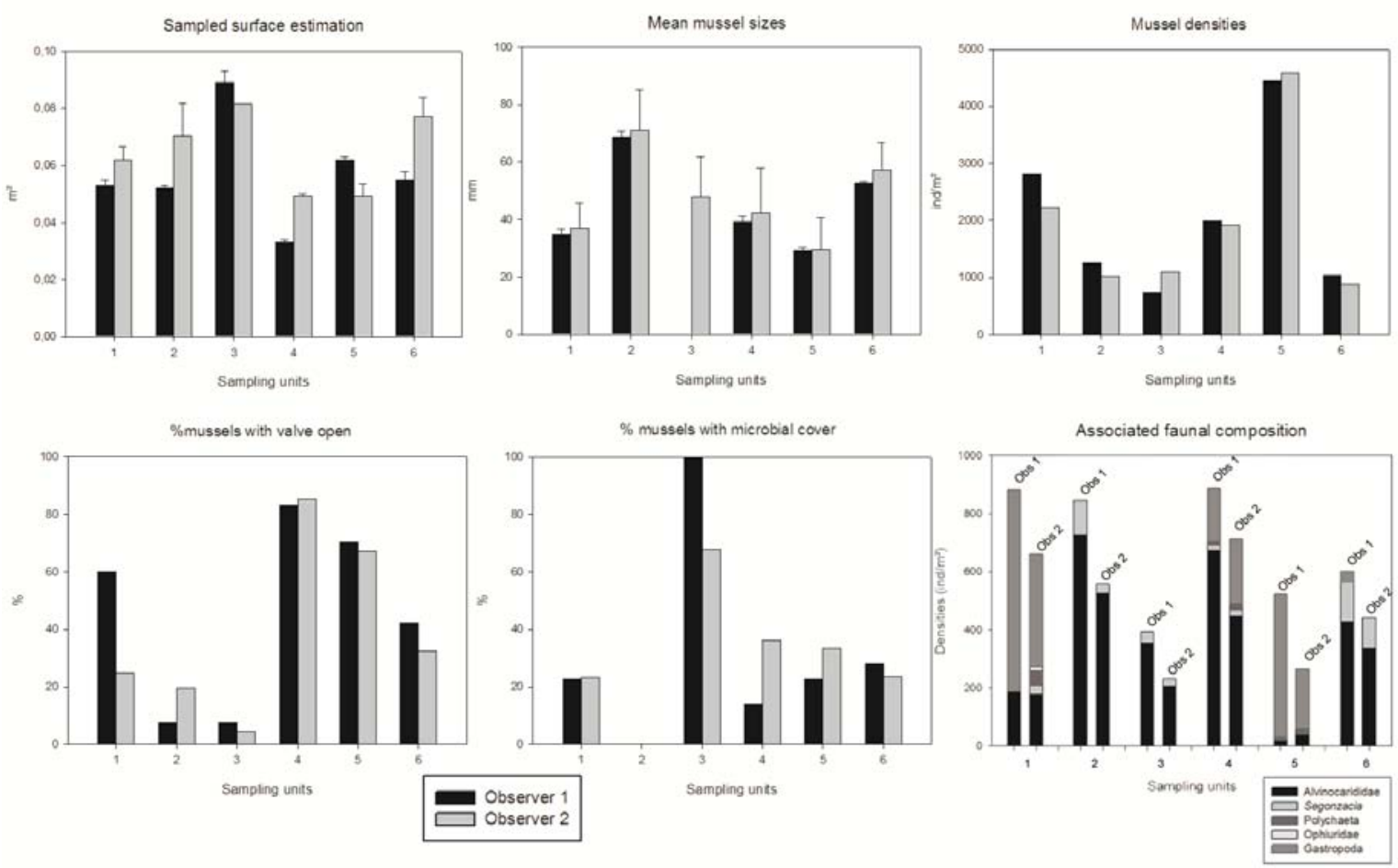

Fig. 6. Illustration of the "observer effect" on different estimations: sampled surface, mussel size and density, percentage of opened mussels and composition of associated fauna. 